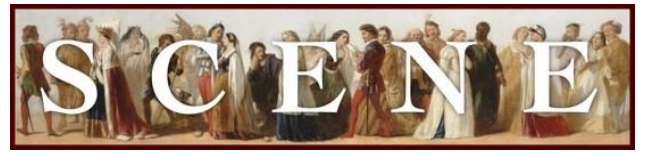

\title{
Bard in the Valley's Taming of the Shrew
}

\author{
by Virginia Cooke. Written on 2016-08-24. Published in 2017 Issue 1.
}

For the production: Taming of the Shrew (2016, Bard in the Valley, Canada). See production details at the end of the review.

JUly 2016 MARKS THE SEVENTH SUMMER FOR BARD IN THE VALley (BRITISH COlumbia's FRASER Valley), the annual month-long run of a Shakespeare play in Langley, B.C. The outdoor performances take place in three venues: the village of Fort Langley, Douglas Park in Langley City, and the grounds of the Township 7 Winery in rural Langley. The winery has advantages over the other settings: no outside noise from passing vehicle and pedestrian traffic, a lovely setting, a sold-out house (capacity measured by available parking), and an audience already cheered by a glass or two of wine. Furthermore, as there is an admission charge, viewers are more committed to the play than those who attend the free showings.

The Bard actors are a young company. Several are recent graduates of the theater program at the University of the Fraser Valley, and a few teach drama at the local high schools. However, the productions themselves involve a myriad of community volunteers - about sixty in all, dedicated to "One Goal, One Passion, Shakespeare for All." For example, the production team draws from The Langley Players Drama Club (founded in 1969), and there is a good deal of local talent and good will.

The choice of play for this year was Shakespeare's early comedy, The Taming of the Shrew. Most audiences are familiar with the main story of Baptista Minola of Padua and his two daughters, the highly desirable Bianca and her sister Katherina known as "the shrew." They are prepared to watch the bombastic Petruchio ruthlessly "tame" his prey, though typically directors struggle to make these actions entirely palatable to today's viewers. Of course, this play, as all Shakespeare's comedies, also involves disguises and mistaken identities, as well as clever servants whose antics bolster the comedy.

Less familiar to audiences is the frame story (the "Induction"), which precedes the main story and involves the tricking of Sly, a drunken tinker, into believing he is a fine lord only just reviving from a coma. The pretext for the Kate/Petruchio story is that some traveling players will perform before Sly and his supposed lady "a pleasant comedy" and "a kind of history." 
Anyone directing Taming of the Shrew must decide whether to include the Induction; often it is omitted, as there is already a good deal of exposition in the opening scenes of the main story before the plot can get rolling.

The Bard in the Valley company and director Darcy Knopp made the curious decision to omit the Induction with Christopher Sly, but to include a different induction of their own devising. Their frame story is set in contemporary times at the Padua Golf and Country Club, where Madame B. discovers to her horror that she has double booked in her banquet hall the major social events for her two primary clients. Both clients, armed respectively with a golf club and tennis racquet, are privileged and demanding - even abusive - and the situation appears irretrievable until Madame B.'s overworked assistant invents a plan to involve both groups of clients in a dramatic performance. In consequence, Madame B. passes out the scripts (of the "Shrew" story) to the competing groups, tells them to ready themselves to play roles in the drama that evening - and therein lies the excuse for the play-within-the-play. However, even the frame story contains a frame, as Madame B. opens with a "do you remember that awful time when ..." and so introduces a memory of the fateful evening.

Once the actors emerged from the Induction and entered Shakespeare's play, they, and the audience, were on more solid footing. The actors managed admirable clarity, given the outdoor setting, and sound and lighting design (run that night by Jim Garnett) supported them well. Bianca's suitors (Jeff Hacker and Nikola Trotzuk) seemed appropriately eager, and Dylan Coulter as Lucentio plummeted convincingly into the depths of love at first sight. The servants Grumio and Tranio were cast as women (Dayna Thomas and Madison McArthur), and came pretty close to stealing the show, Thomas with her zany foolishness and McArthur with calm, inventive solutions to every problem. Tranio masquerading as her master Lucentio was no more strange than the many other women in Shakespeare's plays who disguise themselves as men.

The choice of mother rather than father Baptista had some advantages when Petruchio came courting: his charms may have been lost on Kate, but they certainly worked on her mother. What I missed in this production was a growing chemistry between Petruchio and Kate (Aaron Holt and Mandy Dyck). She first appeared sporting a tennis racquet (perhaps meant to connect with the young spoiled woman in the induction), clearly annoyed with everyone, and a match for Petruchio's brashness. In the closing scene, Kate played her conversion straight, including the speech which gives today's directors and audiences such grief ("Thy husband is thy lord, thy life, thy keeper/Thy head, thy sovereign," etc.). While she seemed unbowed, the discourse lacked playfulness, as did the earlier turning point in her taming when she agrees to call the sun the moon ("What you will have it named, even that it is"). One wondered whether Petruchio had finally simply worn her down. Perhaps because of the contemporary setting, an audience might 
expect some acknowledgement of the misogyny in the script, though this audience seemed content enough.

The set, which had to be portable, was minimal - a simple façade with the sign "Padua Golf and Country Club." This was replaced by a "Gruff Estates" sign when the action moved to Petruchio's home, but there wasn't much visible to emphasize the contrast. Reference to the Country Club setting returns me to the Langley Players' induction, which still leaves me puzzled. With Shakespeare's Christopher Sly story, one can find parallels with the main narrative: for example, the Lord's manipulations can be compared with Petruchio's; Sly's pretend "wife" vows obedience, and then denies her "husband's" first request; the element of disguise runs through both stories. With the Golf and Country Club induction, I had much more trouble finding connections. Were the strong-willed clients meant to echo Petruchio and Kate? Like Tranio, Madame B.'s clever assistant did find solutions. Was I to think that performing the play would bring harmony between the clients competing for the banquet hall?

Director Darcy Knopp does offer this note in the program: "We have transformed Shakespeare's Padua into a modern day golf and country club where rules are rules unless you are wealthy, pretty, or clever enough to bend them." Having gone to the effort of creating the frame story, tossing in occasional late $20^{\text {th }}$ century cultural references (to Clark Kent, for example) and music (The Monkees' "I'm a Believer"), the company might have done well to imbue the production with more social or geographical relevance, and then to follow that through in teasing out more issues in the play.

Still, this is an admirable company which plays a significant cultural role in a community just removed enough from Vancouver that residents might not often see Shakespeare's plays live. Their work is lively, skilled, and well worth seeing.

Virginia Cooke is Professor Emeritus at the University of the Fraser Valley. She is a scholar and teacher of dramatic literature, with particular emphasis on twentieth century Irish theatre, Canadian theatre, and theatre history. Cooke has published and presented work on Samuel Beckett, Brian Friel, and Canada's Headlines Theatre, the British Guild Players (Vancouver's principal stock theatre during the 1930s), as well as Writing Across the Curriculum. 


\section{Production Details}

\section{General}

Title Taming of the Shrew

Year 2016

Theater Company Bard in the Valley

Start Date

2016-06-29

End Date

2016-07-31

\section{Cast}

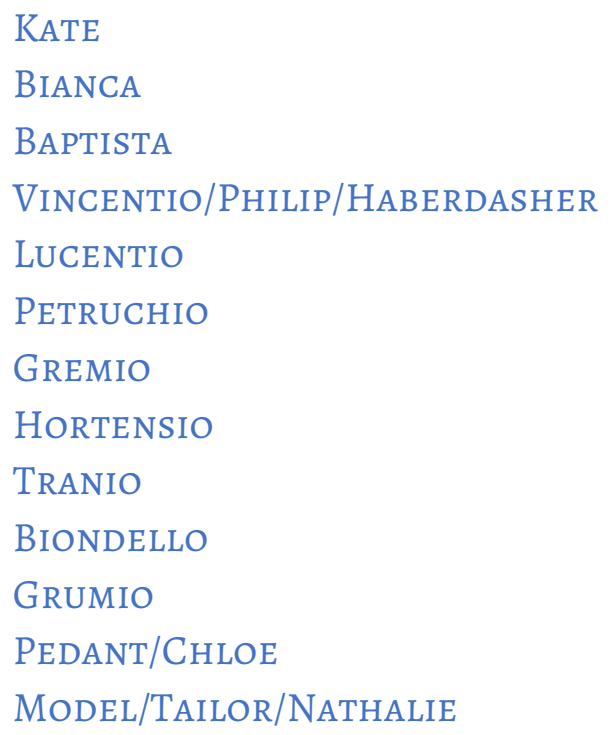

MANDY DYCK

LAUREN TROTZUK

SHERI EYRE

MISHA KOBILIANSKY

Dylan COUlTER

AARON HOLT

JEFF HACKER

Nikola Trotzuk

MADISON MACARTHUR

PAULINE DYNOWSKI

DAYNA THOMAS

SARAH CAVALLI

Kailea De Leon

\section{Creatives}

DIRECTOR DARCY J. KNOPP 